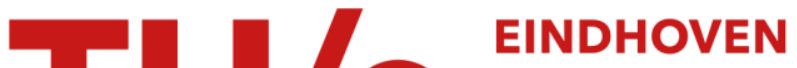 \\ UNIVERSITY OF \\ TECHNOLOGY
}

\section{Perception of anthropomorphistic expressions in software manuals}

Citation for published version (APA):

Mulder, M. N. (1996). Perception of anthropomorphistic expressions in software manuals. Journal of Technical Writing and Communication, 26(4), 489-506.

Document status and date:

Published: 01/01/1996

\section{Document Version:}

Publisher's PDF, also known as Version of Record (includes final page, issue and volume numbers)

\section{Please check the document version of this publication:}

- A submitted manuscript is the version of the article upon submission and before peer-review. There can be important differences between the submitted version and the official published version of record. People interested in the research are advised to contact the author for the final version of the publication, or visit the $\mathrm{DOI}$ to the publisher's website.

- The final author version and the galley proof are versions of the publication after peer review.

- The final published version features the final layout of the paper including the volume, issue and page numbers.

Link to publication

\section{General rights}

Copyright and moral rights for the publications made accessible in the public portal are retained by the authors and/or other copyright owners and it is a condition of accessing publications that users recognise and abide by the legal requirements associated with these rights.

- Users may download and print one copy of any publication from the public portal for the purpose of private study or research.

- You may not further distribute the material or use it for any profit-making activity or commercial gain

- You may freely distribute the URL identifying the publication in the public portal.

If the publication is distributed under the terms of Article $25 \mathrm{fa}$ of the Dutch Copyright Act, indicated by the "Taverne" license above, please follow below link for the End User Agreement:

www.tue.nl/taverne

Take down policy

If you believe that this document breaches copyright please contact us at:

openaccess@tue.nl

providing details and we will investigate your claim. 


\title{
PERCEPTION OF ANTHROPOMORPHISTIC EXPRESSIONS IN SOFTWARE MANUALS
}

\author{
MONIQUE N. MULDER \\ Eindhoven University of Technology, Eindhoven \\ Utrecht University, Utrecht
}

\begin{abstract}
Metaphors and analogies can be helpful for people when they have to learn or learn to use something. Some empirical studies into the effect of metaphors in software manuals showed a positive influence on computer task performance, although this influence proved to be a conditional one. A necessary condition must be that readers understand the metaphor used; readers must have knowledge about its source domain. The most understandable concept for all humans seems to be a human being; the metaphor with human beings as a source domain is called personification or anthropomorphism. Up to now, no coherent theory has been available about linguistic expressions that can be labeled as anthropomorphism, and no empirical data have been gathered about expressions in software manuals that are perceived as such by readers. Therefore, an explorative experiment with real manual material was carried out. Expressions suggesting that computers or programs have feelings or an affective relationship to the user, that they are able to perform non-routine (mental) activities and communicate their intentions through human language use, appear to be perceived as anthropomorphistic. Such expressions might help readers to use a computer (program) more easily.
\end{abstract}

\section{INTRODUCTION}

Software manuals are written to help users understand and use a (new) computer program. Writers of manuals therefore have to make choices in how to convey knowledge about the computer (program) to their readers. Those choices have to be made for all features of document design, such as form features-graphics, 
headings, typology, paper or on-line, etc.-and content features-global and local organization, conceptual/declarative and procedural information, writing style, terminology, shortness, etc. Researchers in the field of document design address these features to discover which components of instructive documents are most conducive to learning or performing tasks [1-3].

One of the helpful content features appears to be a schema or framework users may keep in mind when interacting with a computer. On the basis of such a framework, a user will be able to formulate expectations of computer and/or user actions, to interpret (re)actions of the computer application, and to solve problems [4-5]. Most evidence for this process is available from studies using expository or school book texts. These studies rather consistently show that metaphors evoke schemata that facilitate recall of the main ideas conveyed by a text [6]. The facilitating effects of metaphors in learning situations are most prominently advocated by Lakoff and Johnson, who argue that we cannot learn new concepts or ideas without the help of metaphors [7]. In their view, people grasp a (new) meaning of something by comparisons to other things. This metaphor theory could also apply to the learning of how to use computer applications.

Until now, insufficient empirical research has been available to arrive at solid conclusions about the role of metaphor in computer surroundings. Most results point at a conditional facilitating effect for the user. An experiment with manual texts containing elaborations (e.g., analogies) on concepts and procedures of a program showed that users benefited from these elaborations by performing computer tasks more efficiently: they performed less actions and needed less time to complete a task [3]. This positive effect is not found in all studies, and not in all circumstances. For instance, a marginal effect of an advanced metaphor is found by Foss, Smith-Kerker, and Rosson [4]; they suppose their old-fashioned office information system metaphor was either poorly understood in detail by readers or not connected closely enough to the target domain, i.e., the tasks that had to be executed with a text editor program. The results of Charney, Reder, and Wells suggest that analogies linked with information about concepts, important for an understanding of the purpose and activities of a computer program, are less helpful than analogies linked with information about procedures that have to be performed by a user [3].

Although the exact conditions in which a metaphor or analogy could work best still have to be studied, one necessary condition must be that the interpreter of the metaphor/analogy knows enough about the source domain, i.e., the concept the thing to be (differently) understood is compared to. If the source domain is poorly understood by the reader, the metaphor will not work $[4,5]$. Therefore, when using a metaphor, writers should know what their audience knows. As it is not always possible to study beforehand what the intended audience knows, it might be most efficient to choose a source domain that is known by most readers in general. That choice gives writers less trouble in finding out which 
knowledge already exists in the minds of their audience and less doubts about whether the metaphor is really understandable.

\section{Explicit Anthropomorphism}

The best known and understandable domain for all people seems to be a human being. Readers are human beings, and in most cases they have experienced a lot of contact with other human beings. The type of metaphor that has human beings as its source domain is called personification or anthropomorphism. In this article, both terms are used interchangeably for all references to physical and psychological human qualities. As Aitchison mentions, this type of metaphor is quite often used: "Certain areas permanently attract a large number of metaphors. An analysis of figurative language between 1675 and 1975 showed that the human body had consistently been the highest source of metaphor for these 300 years [. . .]" [8].

Lakoff and Johnson state that personifications "allow us to make sense of phenomena in the world in human terms-terms that we can understand on the basis of our motivations, goals, actions, and characteristics. Viewing something [. . . ] in human terms has an explanatory power of the only sort that makes sense to most people" [7]. Note that Lakoff and Johnson use understand and explanatory power, in their view personification works like other explanatory metaphors, thus for a better understanding of a (new) concept. Leech remarks on metaphors that "We make abstractions tangible by perceiving them in terms of the concrete, physical world; we grasp the nature of inanimate things more vividly by breathing life into them; the world of nature becomes more real to us when we project into it the qualities we recognize in ourselves" [9]. Like Lakoff and Johnson, Leech stresses the clarifying force of metaphor. However, he also describes a possible motivational effect of animation ("breathing life into") and personification by using more vividly and more real.

So anthropomorphism seems a strong and much used instrument to make the nature of (new) things clear or appealing to audiences. In software manuals, writers could provide this human framework by personifying computers and programs. In a brief Dutch introduction manual for the new Windows software, Windows95 voor Dummies, one of the first paragraphs is about the function of this operating system. It says, in translation:

(1) A computer needs somebody to open the door whenever the bell is ringing; a butler to show guests their rooms, stall their luggage, somebody to keep score of the bills and keep an overview of who is sharing a room with whom.

In (1) the operating system is described and labeled as a butler. If we take the commonly practiced definition of personification, which states that when a nonliving object is described as a person the intended metaphor is personification, 
then this is a good example [7, 9-11]. In analyzing explicit cases like (1), the circularity in this definition is no problem because everybody would agree that a butler is a (certain type of) person.

\section{Implicit Anthropomorphism}

Lakoff and Johnson have shown that metaphors are not always used explicitly, but that the terms we describe processes or states with often arise from an underlying metaphorical model. Evidence for this claim is presented by them in Metaphors we live by, but also by Reddy [12]. Reddy lists lots of expressions about communication that fit into one metaphor, which he named the Conduit Metaphor. When talking about communication processes, we use expressions like "get ideas across," "give someone an idea," "this sentence contains the following thoughts," "catch the idea." These expressions must arise from a communication model in which ideas can be put into packages that are moved from one place or person to another, thus a transport model.

In deciding which implicit expressions reveal an underlying model of a person, the commonly used definition of personification-describing something as a person-becomes problematic. It remains unclear what exactly is meant by a person. That might explain why two terms are used in literature for the same or very alike expressions: animation (in the sense of "regard something as alive") and personification.

(2) The car is thirsty.

(3) Inflation has attacked the foundation of our economy.

(4) An angry sky.

(5) A friendly river.

Example (2) is presented by Way, who adds: "This is an example of personification or animation [. . .]" because of the use of thirsty in combination with a non-living sentence subject [10]. She does not comment on a possible difference between animation and personification. Example (3) originates from Lakoff and Johnson and is labeled "personification" by them because of the use of attacked in combination with a non-living sentence subject [7]. Lakoff and Johnson do not mention the term animation. Leech gives (4) as an example of an "animistic metaphor," because of the usage of angry [9]. According to Leech, animation must be different from personification since he gives example (5) and labels this as an "anthropomorphistic metaphor" because of the use of friendly.

The problem that rises when comparing these examples is the unpredictability of the labels used for these expressions. Leech makes a distinction between animistic and anthropomorphistic metaphors but the reasons for this distinction remain unclear. One of the few attempts to define characteristics of persons and their uniqueness compared to other living beings is done by Chisholm [13]. His formal definition that "a person is an individual that is necessarily so that 
it is physically possible that it undertakes action to achieve a goal" is paraphrased by himself as "a person is somebody who is capable of intentional actions." Although not all actions that people undertake need to be performed intentionally or consciously, Chisholm states that persons can in principle be conscious of their actions, and that persons are different in that respect from other actors like animals or natural forces.

From Chisholm's definition, it can be derived that intentional (action) verbs must express some underlying model of persons. Lakoff and Johnson's example (3) would fit into this line of thought. In most languages this underlying human model indeed shows when the potential candidates for subject positions are concerned. Linguists like Jackendoff or Delancey argue that in most languages only humans can be the subject of an intentional (action) verb and therefore be an actor [14-15]. If a non-human thing is connected with such a verb, the sentence literally becomes ungrammatical and must be regarded as a special case, such as a fairy tale sentence or, in text types that are not fairy tales, a metaphor. Following this argument, what would the analysis be of the next sentence, translated from the Dutch manual SURFnet gids 1993 about global computer networks?

(6) Some host computers assume that your terminal takes care of the breaking off of lines that do not fit onto the screen.

Assuming and taking care of are mental and intentional actions, not normally ascribed to non-living things; because they are mental and intentional, these terms must derive from a metaphorically used human domain. However, would every reader and linguist agree with the label of personification for (6)? As the examples (2)-(5) show, it is not expected that linguists would agree on labeling of these expressions; neither it is known whether readers would agree.

Whatever objectively defined label linguists (or psychologists or philosophers) could arrive at-if at all possible considering the fuzziness of concepts and debates on consciousness in humans and animals-the main question would be: what expressions are perceived by readers as personification? The view of anthropomorphism as a strong tool for understanding only holds if the reader perceives a comparison to human beings. Until now, no empirical data have been at hand about the precise text features that are perceived as personification by readers. To gather some initial information an explorative experiment was carried out, in which subjects were asked to judge sentences occurring in software manuals. On the basis of the human characteristics described above, the expressions in these sentences were more or less likely to be perceived as anthropomorphistic or animistic. However, no real hypotheses could be formulated because of the inconsistent labels and insufficient arguments for labeling found in literature. 


\section{MATERIAL}

Sixty sentences-thirty-one quoted literally from existing Dutch software manuals, ${ }^{1}$ and twenty-nine constructed from the same manuals-were presented on paper. In each sentence one word was underlined, such as computer, program, terminal, screen, host computer, network, "program name," software, operating system or it. The rest of each of the sentences gave some information about the underlined word, e.g., its action(s), its quality or state. In most cases the underlined word was the (subordinate) clause's subject. A variety of verbs was linked to these subjects, some of them intentional in Jackendoff's sense and comparable to example (3) mentioned in the introduction. Other verbs indicated mental processes such as "think" or "remember," referring to the human consciousness. In some cases, the underlined word was described with adjectives like "friendly" or "tiptop," comparable to the examples (2), (4), and (5) mentioned in the introduction. Examples of the sentences used are given in Appendix A. The sentences were arranged in two ways, resulting in two booklets different in order, to be able to track context influences.

\section{SUBJECTS}

Forty-four university students took part, all freshmen in Dutch Linguistics and Literature. They were randomly assigned to one of two versions of the sentence booklet.

\section{INSTRUMENTATION}

The sentences were presented in a twelve-page paper booklet, with five sentences on each page. A triangle scale with six categories for judgment (see Figure 1) was printed below each sentence. Three categories were "main categories," three "between two main categories." The meaning of these categories were explained to the subjects as follows:

$A=$ Animate (underlined word is represented as alive)

$\mathrm{P}=$ Person (underlined word is represented as person)

$\mathrm{N}=$ Not alive (underlined word remains a non-living thing)

${ }^{1}$ Manuals: Windows95 voor Dummies (1995, Addison Wesley Nederland BV); Aan de slag met dBASE IV 1.5 (1992, Nan van der Storm, Zutphen: Koninklijke Wöhrmann); dBASE IV voor gevorderen (1988-1990, Ashton-Tate Corporation); Werken met PageMaker voor de Macintosh (1989, C. J. Weigand, vertaald door L. Guerts, Schoonhoven: Academic Service); SURFnet gids 1993 (SURFnet bv Utrecht, Houten: Van Rossum); Harvard Graphics: van Dos naar Windows (1992, Software Publishing Corporation, Great Britain: Donnelley Documentation Services); Framework III, Toepassingen en technieken (1989, Henk de Groot, Deventer: Kluwer Technische Boeken B.V.); Basisboek Ventura versie 2 (1990, Kees Schouten, serie PC Training \& Toepassing, Groningen: BoekWerk). 


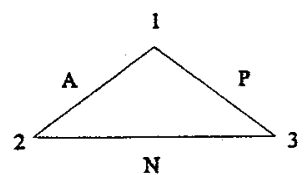

Figure 1. The triangle subjects used to categorize the underlined word.

$1=$ representation is somewhere in between Animate and Person

$2=$ representation is somewhere in between Animate and Not alive

$3=$ representation is somewhere in between Person and Not alive

The triangle form was chosen because of the need for categories in between Not alive and Person on the one hand, and Not alive and Animate on the other. For some apparatus it has gradually become normal to speak about it in originally human or animistic terms; a motor is "running" and typewriters "write," although the traditional meanings of these verbs suggested living beings with legs or hands and brains. One could judge this kind of information as person-like or animisticlike, but not really personification or animation. A triangle scale provided in the need for these two in-between categories equally far from $\mathrm{N}$.

\section{PROCEDURE}

The experiment was carried out in two successive student groups of a first semester course. Each group received an oral, classical instruction after reading a written individual instruction. The students were told to engage in an experiment that was part of a larger study about the way people perceive computers and software programs. They were asked to judge to which of the triangle categories the underlined word could belong, on the basis of the information in the rest of the sentence. They were given two examples, reported here in translation.

\footnotetext{
If you read the sentence: "This program is as smart as the best student of the year," you may think the program is represented as a person. If so, circle $P$ on the triangle scale. If you read the sentence: "The computer has to be woken with the help of DOS," you may think the computer is represented as a living being. Put a circle around $\mathrm{A}$.
}

It was emphasized that the subjects had to fill in their very own judgments. The in-between categories had to be circled when no main category was really expressing their judgment. Subjects were asked to read and judge the sentences 
in the order they were given and not to return to pages they had turned over. It took subjects fifteen to twenty minutes to judge all sentences. A week later the subjects were debriefed about the meaning of the experiment, along with a presentation of the results.

\section{DATA ANALYSES}

The data were analyzed with the statistical package SPSS. Data of two subjects who skipped some pages were left out of analysis. Frequency tables of all six categories were generated. To check for order effects between the two versions of the booklet, a $T$-test was executed.

Additionally, two Cluster Analyses were carried out. Cluster Analysis can be applied when models or theories still have to be developed and no hypotheses are available. Results of such an analysis show the degree to which it is agreed that certain items belong to the same group. In one of the two Cluster Analyses sentences were used as an independent variable; this analysis would reveal groups of sentences that are more or less equally judged. In the second Cluster Analysis subjects were used as an independent variable; this analysis would show groups of subjects that more or less resembled each other in their judgment behavior.

Since Cluster Analysis uses distances between scale points of the dependent variable as a basic computing measure (Squared Euclidian method), it appeared necessary to divide the triangle scale into two halves, thus creating a stable distance between two categories. Defining the distances between the original six categories was problematic, mainly because of the in-between category 3 linking the "low" category $\mathrm{N}$ with the "high" category $\mathrm{P}$.

The first composed category, N', was constructed out of the three original categories on the triangle base and defined as: N' entails judgments equal to or near to $\mathrm{N}$, referring to expressions (close to) neutral to non-living things. The interpretation of the original in-between categories 2 and 3 was: somewhere in between $\mathrm{N}$ and $\mathrm{A}$ or $\mathrm{N}$ and $\mathrm{P}$. Subjects who did not agree with a full $\mathrm{P}$ for some expressions may have chosen category 3 , thus stating that they saw a person-like characteristic in it. In the two category analyses these person-like judgments are filtered out because they are placed into $\mathrm{N}^{\prime}$. The justification for this filtering is that only expressions that are very likely to be perceived as anthropomorphistic are of interest for intended further research. The second category, L', was constructed out of the three original categories on the top of the triangle and defined as: L' entails judgments equally far from N', referring to expressions not neutral to non-living things.

The two composed categories were also used in a Non-Parametric Chi-square analysis of judgments, to confirm whether the judgments of a sentence differed significantly between the two categories. 


\section{RESULTS}

Frequency distributions of three original triangle categories- $\mathrm{N}, \mathrm{A}$, and $\mathrm{P}-$ and the two composed categories- $N^{\prime}$ and L'-are presented in the left half of Table 1. These frequency distributions belong to the sentences labeled in the last alphanumeric column (e.g., sentence 1 is Z01). The Chi-Square test showed that the amount of judgments in the two categories did not differ in twenty-four cases (items with frequency differences between 0 and 12). The rest of the items showed a difference between the two composed categories $\left(\chi^{2}\right.$ between 4.67 and $6.10, p<.05$ for frequency differences between 14 and 16; and $\chi^{2}$ between 7.71 and $34.38, p<.01$ for frequency differences between 18 and 38). In twenty-four cases a sentence was judged as $N^{\prime}$, in twelve cases a sentence was judged as L'. Differences at both p-levels for the composed $\mathrm{N}^{\prime}$ and L' categories are marked by an asterisk in Table 1. No context influences of sentence order on judgments were found.

The sentence labels are also connected with the result of the first cluster analysis, presented in the right half of Table 1 . The dendrogram has to be read like this: the point of connection between item lines refers to a point at the relative distance scale on the top. The smaller the relative distance between items, the more these items are judged equally. Three main groups of items are revealed by this cluster analysis. In Table 1, they are divided by empty lines and numbered correspondingly to the numbers used hereafter.

1 A "Living" Cluster, with a subcluster on the top that can be interpreted as a "Person" Cluster. The amount of original $\mathrm{N}$-judgments in this "Person" Cluster is very low (from 0 to 4), whereas the amount of original P-judgments is very high (from 26 to 33). The four sentences in this "Person" Cluster are:

$\mathrm{Z} 04=$ The program makes a last plea, in tears about its approaching departure. $\mathrm{Z} 52=$ Windows 95 , that fine and helpful friend, helps you to find your way through the programs on your $\mathrm{PC}$.

$\mathrm{Z} 58=$ When you do get used to this program, it appears to be a nice pal to work with.

$\mathrm{Z} 30=$ The program packs its stuff and leaves the screen.

The remaining items of the "Living" Cluster also show low $\mathrm{N}$-frequencies (from 4 to 11), a range from six to nineteen A-frequencies, and a range from six to twenty P-frequencies. Examples of the remaining "Living" Cluster sentences:

$Z 09=$ DBASE now expects us to immediately point at the second linking field. $\mathrm{Z} 10=$ The program asks whether you want to save the changes you made.

$\mathrm{Z} 20=$ One computer thinks $200 \mathrm{~KB}$ is just fine, while another may start to sputter if it has to deal with $20 \mathrm{~KB}$.

Other sentences in this cluster are presented in Appendix A. 
Table 1. Frequencies for Main Original Categories and for the Two Composed Categories per Sentence (Z01 to Z60, " = Significant); and the Result of Cluster Analysis with Sentences as Cases

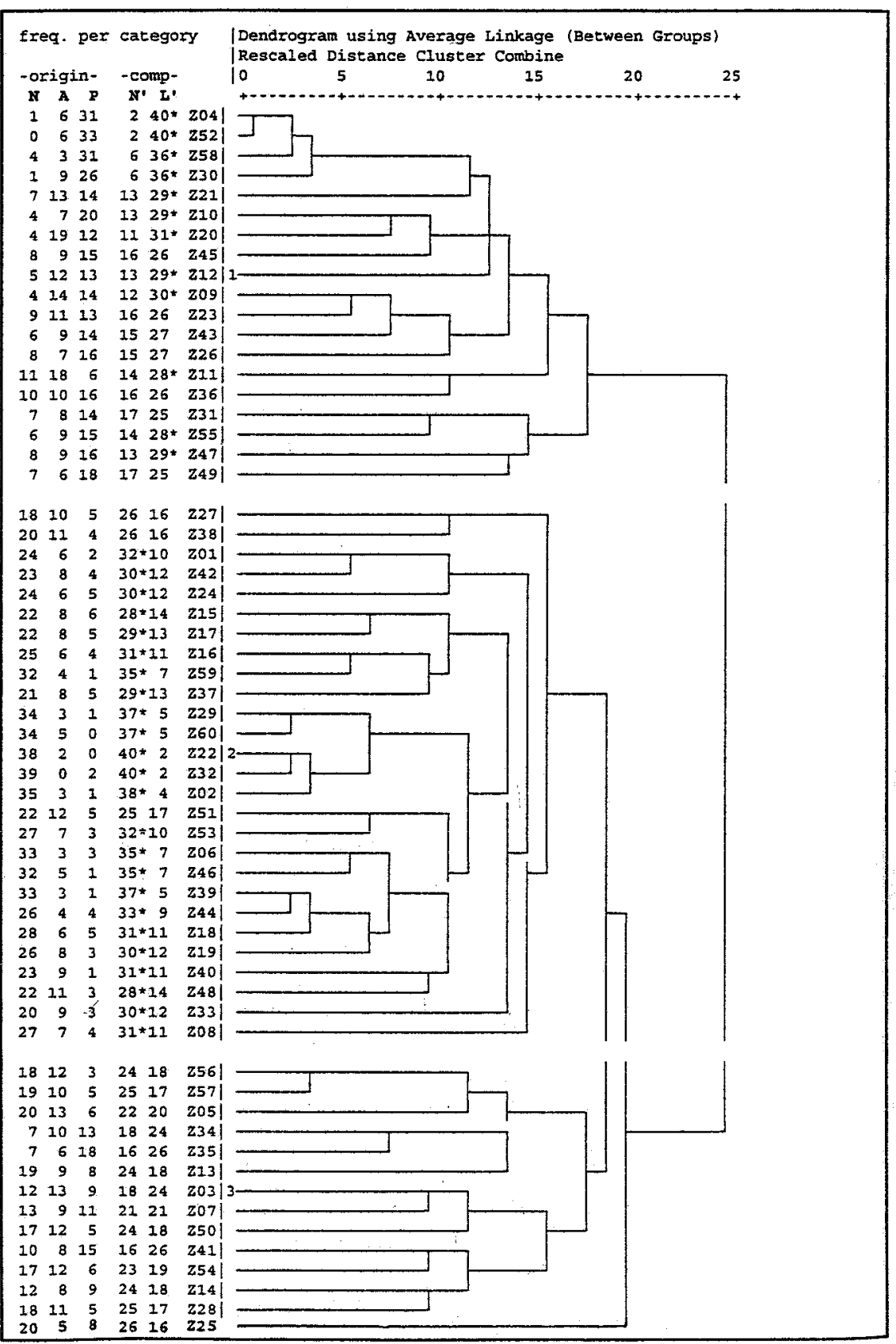


2 A "Non-living" Cluster. In this cluster the amount of original $\mathrm{N}$-judgments is high (from 18 to 39) and the amount of P-judgments is very low (from 0 to 6). At the core of this cluster are the sentences:

$\mathrm{Z} 22=$ This program is a splendid tool for enlargening your productivity.

$\mathrm{Z} 32=$ The starting screen of this program appears on your monitor.

$\mathrm{Z} 29$ = Ventura has (in Dutch: "knows") a variety of lay out functions.

$\mathrm{Z} 60=$ The progr. $\mathrm{m}$ functions at its best when your hard disk has $4.5 \mathrm{MB}$ of free space.

Other sentences in this cluster are presented in Appendix A.

3 A "Doubt" cluster. The sentences in this cluster show a lot of variation in judgments. All sentences in this cluster are presented in Appendix A.

In the second cluster analysis, subjects instead of sentences were used as an independent variable. This analysis also revealed three main clusters.

- $\mathrm{N}^{\prime}$-oriented subjects (21 subjects, amount of judgments in N' from 34 to 60). Three of them never circled a $P$, one of which neither circled any $A$. In this cluster the highest amounts of the original category 3 , in between $N$ and $P$, were counted. Three subjects used this in-between category seventeen, eighteen, or twenty-four times. Other subjects made heavy use of the original category 2 , in between $\mathrm{N}$ and $\mathrm{A}$; they circled this category up to seventeen, eighteen, or twenty-four times.

- Not clearly oriented subjects (12 subjects, amount of judgments from N' from 23 to 34 and in $L^{\prime}$ from 26 to 38 ).

- L'-oriented subjects (9 subjects, amount of judgments in L' from 36 to 54). Three of them circled a $\mathrm{P}$ thirty-nine, thirty-eight, or thirty-one times; all subjects also used the N-category, from six to twenty-two times.

\section{Cluster Characteristics}

Most of the sentences in the "Non-living" Cluster appear to describe actions at a routine level. Makes (Z01), imitates (Z42), arranges (Z15), interprets (Z17), defines (Z59 and $\mathrm{Z} 44)$, function ( $\mathrm{Z} 60$ and $\mathrm{Z} 46$ ) are all actions that can be imagined to be highly routineous, predictable, and therefore "programmable." Another sentence part also describing this routine function is present in Z22 (tool for enlargening your productivity).

When this routine rule is applied to the sentences in the "Doubt" Cluster, one would expect the sentences Z56, Z57, Z05, and Z13 to yield most judgments in N'. Indeed, those sentences show the highest amount of $N^{\prime}$ judgments. Unexpectedly, the same range of $\mathrm{N}^{\prime}$ judgments is present in Z25 and Z28; looking friendly and remember seem to be just as neutral to the nature of a program. Remember is a mental verb that probably became quite normal for computer programs. Mental verbs are also present in Z41 and Z14. Forget in Z41 yields 
most judgments in L' and a fairly high amount of P-judgments; must know in Z14 shows must judgments in N'. So, whereas mental verbs are quite common in combination with software and computers, the strongly unintentional verb forget seems to be very human-like.

The highest amount of P-judgments in the "Doubt" cluster is present in sentence Z35, in which the expression explains to you is used. Together with other communication verbs like answers ( $\mathrm{Z} 34$ ) and warns (Z03), these kinds of verbs seem to express something belonging to humans. Warns receives more original A judgments, probably because of a lack of explicit medium (it can be noise or flickering), whereas answers and explains point at human language as a medium.

To summarize: expressions indicating routine actions are perceived as neutral in combination with non-living things like computers and software; when it comes to communication or mental verbs, it depends on the strong reference to human language or brain activities whether these expressions are perceived as not neutral to the nature of computers or software. It might be expected that the expressions in the "Living" Cluster refer to non-routine actions, or strongly to human language and brain activities. This seems to be the case.

References to human language use are found in the sentences Z21 (speak a language), Z10 (asks) and Z55 (tells you); references to non-routine mental processes are found in Z20 (think fine), Z12 (deliberately), Z09 (expect), and Z47 (is planning). Two sentences in this "Living" Cluster (Z20 and Z11) receive the highest amounts of A-judgments, because of the presence of words like sputter (no explicit indication of a medium) and centipede (a true animal). In the "Person" Cluster, however, there is more to it than just non-routineness or human language and brain activities.

Makes a last plea (Z04) is a strong reference to a human language activitymaybe even that of a lawyer. But in the same sentence another expression could have led to the P-judgments, in tears about. This expression refers to an emotion that is very recognizable for people; it has a strong affective effect since it suggests we have to pity the poor program that has to leave our companionship. Instead of simply describing that there is a quitting procedure with built-in "points of return" the writer of this manual turned it into a dramatic event. Packs its stuff (Z30) also has a dramatic touch to it; this expression is often used for human beings, for example when leaving a job. In Z52 the operating system is described as a friend; in Z58 the program is a nice pal. These nearly explicit anthropomorphistic expressions, referring to human relationships, are affective as well. They stress the good relationship user and program are supposed to have and make the program appealing to us.

\section{DISCUSSION}

Judging text characteristics of single sentences is far from normal reading behavior. Most readers are not used to classifying their opinion about 
expressions in text. They may have one, but normally it is not that conscious (unless the reader is in some way professionally engaged in writing or reading). Confronted with six possibilities on a judgment scale they might stick to certain categories that are most familiar to them. As the cluster analysis of subjects showed, however, most subjects were quite capable of using more than one category. They seem to be able to recognize differences between expressions, although some subjects stuck to one "core" category and regarded the differences as relatively small (expressed in their use of in-between categories).

The nature of the expressions in the resulting "Person"/"Living" Cluster did not turn out to be classifiable in terms of the human characteristics mentioned in the introduction. The ability to perform intentional and/or conscious actions is not the main characteristic readers seem to have in mind when deciding on anthropomorphism in software manuals. Sometimes unintentional actionse.g., forget, be in tears about, which are, most of the time, not planned with a certain goal in mind-proved to be perceived human-like, whereas intentional or mental actions such as arrange, interpret, define, or remember are thought to be perfectly neutral to computers and software. It might be that these interpretations are not generalizable to other contexts such as manuals for using a video set. The nature of a computer (program) or a video must have an impact on the way readers perceive expressions used in combination with these apparatus. Nevertheless, intentionality and consciousness do not seem to be the most important characteristics that could explain why expressions are perceived as anthropomorphistic.

On the other hand, the proposed more detailed classification of non-routine actions and strong reference to human language and brain activities does not explain all judgments either. Consider sentences that resemble example (5) cited from Leech and labeled by him as anthropomorphistic. Having a friendly, intuitive user interface in $\mathrm{Z} 40$, and other references to the friendly looks of a program in $\mathrm{Z} 54$ and $\mathrm{Z} 25$, elicited a high amount of $\mathrm{N}$-judgments. It seems that the explanation for the neutrality of friendly in combination with an interface must derive from the rather well-known advertisements for user friendly, or, in short, friendly software. This reasoning does not hold for a case in the "Doubt" cluster, Z07. Although the verb read is very commonly used in computer context, exactly half of the judgments were present in both categories $N^{\prime}$ and L'. The twenty-one judgments in $N^{\prime}$ consisted of thirteen original $\mathrm{N}$-judgments, so eight subjects chose in-between categories. Thus read, as an activity strongly referring to human language use, still has something left of its original meaning because most subjects saw it as not entirely neutral to the nature of computers.

In spite of the common assumption in literature that anthropomorphistic expressions would be most understandable to all people, the sentences in the "Person" Cluster cannot only serve an explanatory goal. The affective and dramatic mode of the expressions that were perceived as anthropomorphistic 
by nearly all readers suggests that this metaphor also has a motivating goal. References to human emotions and descriptions of the interaction with computers and software in terms of human relationships seem to stress the pleasantness of working with computers and programs. The other sentences in the "Living" Cluster receive less P-judgments and mainly serve an explanatory goal since they are less dramatic.

\section{CONCLUSIONS}

Expressions in which it is suggested that programs have feelings, have some affective relationship to us, that they are able to communicate intentional activities through human language use and to perform non-routine (mental) activities, appear to be perceived as anthropomorphistic by readers. The characteristics of affection and non-routineness seem to fit well into the common idea of humans as emotional, creative, and unpredictable beings as opposed to computational, automatic, and emotionless machines [16]. The results of this explorative experiment will be used to arrive at testable hypotheses about text characteristics that evoke an anthropomorphic view on computers or software. A text containing such characteristics can be used in true experiments to study their effect on performance of computer tasks.

It is still an open question whether readers will be enabled to perform computer tasks more efficiently when reading anthropomorphic expressions. The strongly anthropomorphizing effect of affective expressions revealed in the reported explorative experiment suggests that anthropomorphism might be most powerful in motivating people to work with computers-which could provide a positive attitude to learning-and that the explanatory power might prove to be less important. These preliminary conclusions also remain to be tested in further experiments.

\section{ACKNOWLEDGMENT}

I wish to thank Huub van den Bergh for his valuable statistical suggestions and patient explanations.

\section{APPENDIX A: \\ Sentences (Original \& Translated) Grouped per Cluster}

\section{Living Cluster}

Z21 Het ene netwerk spreekt een taal die niet zomaar begrepen wordt door elk ander netwerk.

Some networks speak a language that will not be understood unconditionally by other networks.

Z12 Het programma heeft deze verwijdering bewust in twee stappen gedaana, om te voorkomen dat records worden gewist $\mathrm{z}$ onder dat dat eigenlijk moest. 
The program has deliberately executed this deletion in two steps, to avoid records from being erased unintentionally.

Z11 Dit besturingssysteem is een topfitte organisatorische duizendpoot.

This operating system is a tiptop organizational centipede.

Z55 Lotus vertelt $\mathbf{u}$ vervolgens dat de veranderingen opgeslagen zijn.

In addition, Lotus tells you that the changes have been saved.

Z47 Windows95 is nu van plan om alle bestanden van de directory te verwijderen. Wil ja dat niet, klik dan op NEE.

Windows 95 is now planning to delete all files from this directory. If you do not want that, click on NO.

\section{Doubt Cluster}

Z56 PageMaker opent het paginascherm, waarna $\mathbf{u}$ de gewenste tekst kunt inbrengen.

PageMaker opens the page window, after which you can insert the desired text.

Z57 dBASE bepaalt welke namen als eerste op de lijst voorkomen.

dBASE decides which names come first on the list.

Z05 Ventura selecteert uit ieder hoofdstuk uit de publicatie de tekst van de alinea's.

Ventura selects paragraph texts from each chapter of the publication.

Z34 dBASE antwoordt dat er een nieuwe file aangemaakt wordt. dBASE answers that a new file is made.

Z35 Het programma legt $u$ nu uit welke twee opties $u$ heeft om deze handeling uit te voeren.

The program now explains to you which two options you have to execute this operation.

Z13 Lotus rekent de totaalbedragen van elke kolom voor $u$ uit.

Lotus calculates the totals of each column for you.

Z03 De computer waarschuwt $u$ wanneer er al een file met dezelfde naam bestaat.

The computer will warn you if a file with the same name already exists.

Z07 De computer leest de informatie die $\mathbf{u}$ heeft ingevoerd. Wacht tot $\mathbf{u}$ de melding ziet verschijnen dat alle informatie is gelezen.

The computer reads the information you imported. Wait until you see the message that all information has been read.

Z41 Het programma vergeet welke veranderingen $u$ heeft aangebracht als $\mathbf{u}$ deze niet opslaat.

If you do not save the changes you made, the program forgets them.

Z54 Ondanks zijn vriendelijke uiterlijk is het programma niet altijd even makkelijk.

In spite of its friendly looks the program is not always that easy. 
Z14 Het programma moet weten welk veld kan zorgen voor de samenvoeging van de artikelen bij de leveranciergegens.

The program must know which field can take care of joining articles with supplier data.

Z28 Het programma onthoudt de laatste pagina waar $u$ was en laat dat nummer in het dialoogkader zien.

The program remembers the last page you were at and shows that number in the dialogue frame.

Z25 Hoewel het programma er vriendelijk uitziet, slaagt een beginnend gebruiker er vaak niet in zelfs maar een eenvoudige publikatie te maken. Although the program looks friendly, a novice often does not succeed in making even the simplest publication.

\section{Non-Living Cluster}

Z01 Het programma maakt zoveel pagina's als u aangeeft.

The program makes as many pages as you indicate.

Z42 In de meeste gevallen kunt $\mathbf{u}$ terminalproblemen voorkomen door gebruik te maken van een VT100-terminal of van software die een VT100-terminal nadoet.

In most cases you can avoid terminal problems by using a VT100 terminal or software that imitates a VT100 terminal.

Z15 dBASE ordent uw adresbestanden zodat ze op etiketformaat afgedrukt kunnen worden.

dBASE arranges your address files so that they can be printed on a label format.

Z17 Uw terminal interpreteer gegevens van de host als 8-bits tekens terwijl het feitelijk 7-bits tekens zijn.

Your terminal interprets host data as 8-bit signs, whereas they in fact are 7-bit signs.

Z16 Het programma brengt de presentatieschaal automatisch aan, zodat $u$ zich kunt concenteren op de inhoud van uw presentatie.

The program adds the presentation scale automatically, so that you can concentrate on the content of youer presentation.

Z59 Word definieert $h$ et aantal spaties en de regelafstand; $u$ kunt ze echter aanpassen als $u$ dat wilt.

Word defines the amount of blanks and the distance between lines; however, you can adapt those if you want.

Z02 Framework III bevat voorzieningen om die capaciteit zonodig uit te breiden.

Framework III has provisions to enlarge that capacity if necessary.

Z06 Alle programma's hanteren hetzelfde Opslaan-commando.

All programs use the same Save command. 
Z46 Wanneer er meer programma's tegelijkertijd geactiveerd zijn, functioneer het MEL-programma niet zoals het zou moeten.

If more programs are activated at the same time, the MEL-program does not function as it should.

Z19 Het programma zoekt bestanden in een directory met een extensie als zoekvoor-waarde.

The program searches for files in a directory with an extension as a search condition.

Z40 Dit programma is de eerste keus, voornamelijk omdat het een vriendelijke, intuïtie-ve gebruikersinterface heeft.

This program is first choice, mainly because of its friendly, intuitive user interface.

\section{REFERENCES}

1. W. Horton, The Icon Book. Visual Symbols for Computer Systems and Documentation, John Wiley \& Sons, Inc., New York, 1994.

2. J. Price, How to Write a Computer Manual -A Handbook of Software Documentation, The Benjamin/Cummings Publishing Company, California, 1984.

3. D. Charney, L. Reder, and G. Wells, Studies of Elaboration in Instructional Texts, in Effective Documentation. What We Have Learned from Research, S. Doheny-Farina (ed.), MIT Press, Cambridge, pp. 47-72, 1988.

4. D. J. Foss, P. L. Smith-Kerker, and M. B. Rosson, On Comprehending a Computer Manual: Analysis of Variables Affecting Performance, International Journal of ManMachine Studies, 26, pp. 277-300, 1987.

5. J. M. Carroll and J. C. Thomas, Metaphor and the Cognitive Representation of Computing Systems, IEEE Transactions on Systems, Man, and Cybernetics, SMC-12:2, pp. 107-116, 1982.

6. J. Gallini, M. Seaman, and S. Terry, Metaphors and Learning New Text, Journal of Reading Behavior, 27:2, pp. 187-199, 1995.

7. G. Lakoff and M. Johnson, Metaphors We Live By, The University of Chicago Press Ltd., Chicago/London, 1980.

8. J. Aitchison, Words in the Mind-An Introduction to the Mental Lexicon, Basil Blackwell Ltd (UK), Oxford, 1978.

9. G. N. Leech, A Linguistic Guide to English Poetry, Longman, London, 1969.

10. E. C. Way, Knowledge Representation and Metaphor, Studies in Cognitive Systems, Vol. 7, Kluwer Academic Publishers, Dordrecht, 1991.

11. E. F. Kittay, Metaphor: Its Cognitive Force and Linguistic Structure, Clarendon Press, Oxford, 1987.

12. M. Reddy, The Conduit Metaphor, in Metaphor and Thought (2nd Edition), A. Ortony (ed.), Cambridge University Press, Cambridge/NY/Melbourne, 1993.

13. R. M. Chisholm, Person and Object, A Metaphysical Study, George Allen \& Unwin, Ltd., London, 1976.

14. R. Jackendoff, Semantics and Cognition, MIT Press, Massachusetts, 1983. 
15. S. Delancey, Notes on Agentivity and Causation, Studies in Language, 8:2, pp. 181-213, 1984.

16. S. Turkle, The Second Self. Computers and the Human Spirit, Simon \& Schuster, New York, 1984.

\section{Another Article On Communication By This Author}

M. Mulder, Metaphors in Software Manuals, in Processing Forum95, M. Steehouder (ed.), INTECOM (International Council for Technical Communication), Dortmund, 1995.

Direct reprints requests to:

Monique Mulder

Eindhoven University of Technology

Technology Management, TEMA 0.24

P.O. Box 513

$5600 \mathrm{MB}$ Eindhoven

The Netherlands

Telephone +31 402472415

E-mail M.N.Mulder@tm.tue.nl 